\title{
Explanatory Notes of Homographs From Elementary Chinese Textbooks Published in Japan*
}

\author{
GE Jing, YIN Ling-wei \\ North China University of Technology, Beijing, China
}

\begin{abstract}
Homographs play a vital role in textbooks. Therefore, the focal point for learners is how to master these words and reduce the misusage. Chinese and Japanese share a large quantity of homographs due to the usage of Chinese characters, leading to misusage for Chinese learners. Because of the "visual identical" effects, Chinese learners in Japan often neglect the semantic differences. This paper is designed to study the explanatory notes of homographs in current 16 elementary textbooks which are published in Japan. The findings in many textbooks only include pinyin notes and simple explanations. From the author's aspect, focusing on the vocabulary teaching may reduce misusages, thus plays a positive role in mastering the meanings and usages of homographs.
\end{abstract}

Keywords: Chinese textbooks published in Japan, explanatory notes, homographs between Chinese and Japanese

\section{Introduction}

Cook (2000) points out that learners may unconsciously fill in the unknown part of knowledge in the second language learning by using their own mother tongue. It may have better effects for the two closely-correlated languages. Since Chinese and Japanese is in the same category of languages, the principle applies in it. A multitude of homographs exist in Chinese and Japanese. Okochi (1992) gives the definition of homographs as following:

同形語は「政治、文化」のように日・中で字面が同じ単語である。双方同じ漢字（簡体字は問わない）で 表記されるものを同形語と呼ぶ。(p. 179) (Homograph refers to “politics, culture” and so on, Chinese and Japanese share words with identical literal meanings. Those words using the same Chinese characters (both in simplified Chinese and traditional Chinese) are called homograph.)

As the definition shown, homographs in Chinese and Japanese only refer to the words with same forms not the ones with same meanings. These two languages fall into same linguistic category, and share some overlapping parts in forms and meanings. Therefore, Chinese is fairly easy for beginning learners with Japanese linguistic background. In the meantime, because of “visual identity"「視覚的同一性」(Arakawa, 1979), Chinese learners tend to neglect differences of meanings. For instance, "heart-warming", "amiable", and "certain" share same forms in two languages (“热心”, “亲切”, “一定” in Chinese, 「熱心」、「親切」、「一定」 in Japanese). Thus, it is easy to study for Chinese learners in Japan. However, those overlapping in literal meanings would

\footnotetext{
* This paper is funded by "North China University of Technology Cultivation for Outstanding Young Teachers Program": study on the Chinese teaching as a second language in China, Japan, English-speaking countries and Germany.

GE Jing, lecturer, Ph.D., Japanese Department, North China University of Technology.

YIN Ling-wei, lecturer, master, Chinese Department, School of Humanities and Law, North China University of Technology.
} 
lead to oblivion of semantic differences and make many mistakes. This kind of misusage closely associates with over simplified explanations in elementary of Chinese textbooks.

According to SHI Jian-jun's (2013) statistics, the study of homographs published by scholars in two countries has more than 300 pieces, roughly on "Vocabulary Exchange on Chinese and Japanese (in different time periods), Comparison in Word System between Chinese and Japanese (during same time period), and Usage Comparison in Meanings of Homographs between Chinese and Japanese". This paper is aimed to study the explanatory notes of homographs in current 16 elementary textbooks which published from 2006 to 2008 in Japan, discovering disadvantages of those notes and seeking better solutions.

\section{Problems}

First of all, take the word "heart-warming" (热心 in Chinese) as an example, to find out problems. The explanations of these words in dictionary are shown as follows:

热心 : 有热情、有兴趣、肯尽力。(热心 : enthusiastic, interested in something, make efforts)

親切: 人情の厚いこと。親しくねんごろなこと。思いやりがあり、配慮のゆきとどいていること。 親切に教える。親切な人。(considerate: like to take care of others.)

In the elementary textbook Approach to Chinese, the explanation of “热心” (heart-warming) is “親切だ” (heart-warming). The example is as follows:

Example (1) 我们老师很热心。

Example (1) may have two versions of translation:

a. 私たちの先生は極めて親切な人だ。/Our teacher is very heart-warming.

b. 私たちの先生は世話を焼くのが好きな人だ。/Our teacher likes to take care of others.

According to the explanatory notes in the textbook, A is used in the textbook, but B is more consistent with the original meaning. The first explanation of「熱心」 is “be zealous about doing something”. Therefore, the explanation as "heart-warming" (「親切だ」) may be not appropriate.

Example (2) 他对汉语学习很热心。/彼は中国語の勉強に対してとても熱心だ。/He is very enthusiastic about Chinese learning.

Like “热心” in Example (1), this word in Example (2) also acts as adjective in the sentence. Nevertheless, students would translate it as follows, according to the explanation of "heart-warming” (「親切だ」) in the textbook:

*彼は中国語の勉強に対してとても親切だ。

*He is very heart-warming about Chinese learning.

Clearly, this sentence is incorrect. Compare Examples (3) and (4):

Example (3) 他是热心人/彼は親切な人だ $\rightarrow$ (人が親切である)

He is a heart-warming person.

Example (4) 他热心帮助别人/彼は他人を助けることに熱心だ（他人を助けることに熱心である)

He is enthusiastic about helping others.

From the Examples (3) and (4), Chinese "heart-warming” (“热心”) has two different meanings (“amiable” to people and "enthusiastic" about something). Unfortunately, it indicates only one meaning as "heart-warming" (「親切だ」). This simple explanation is obviously not rigorous. Then how can it help learners to effectively master the semantic meanings and usages of homographs? The author believes that the better solution is focusing on vocabulary teaching. 


\section{The Number of Homograph and the Current Explanatory Notes Methods}

This paper is aimed to study the explanatory notes of homograph in current 16 elementary textbooks which published from 2006 to 2008 in Japan, and also study the number of new words and homographs, and percentage of the homographs accounting for new words. The study result is as shown in Table 1.

According to the syllabus of HSK test (HanyuShui Ping Kaoshi: Chinese Profiency Test as a Foreign Language) Level Two in 2011 Version, the requirement of vocabulary is 300 words and 600 words for Level Two and Three respectively. From Table 1, the number of new words varies vastly: The most is Standard Chinese 1 ( 873 new words), the least is Progress Everyday (256 new words), and the average is 502 new words. According to ZHANG Ying (2001), the most is 510 new words, and the least is 161 new words. Comparing the number of new words in textbook published from 2006 to 2008, the authors can see the increase of number of new words in the latest decade. The largest number of homographs is 288 , the smallest is 22 , and the average is 102. The number of new words in Standard Chinese 1 is 873,49 homographs among them, accounting for $5.6 \%$, which is the lowest percentage. However, the number of new words in Happy Chinese is 371, 143 homographs among them, accounting for $38.5 \%$. The rest of textbook accounts for from $15 \%$ to $25 \%$, the average percentage would be $19.0 \%$. The authors can roughly say that the number of homographs has a large share in the beginning study phase.

Table 1

No. of New Words and Homographs in Textbooks

\begin{tabular}{lccc}
\hline Textbook & No. of new words & No. of homographs & Percentage of homographs (\%) \\
\hline To the Chinese & 413 & 83 & 21 \\
Kumi Shanghai Trip & 487 & 95 & 19.5 \\
Chinese College & 602 & 131 & 21.8 \\
Chinese Time & 589 & 77 & 13.1 \\
Chinese Bridge & 559 & 91 & 16.3 \\
Campus Life in Chinese & 493 & 121 & 24.5 \\
Open the door! Chinese & 661 & 161 & 24.5 \\
Instantly use Chinese & 401 & 54 & 13.5 \\
Progress Everyday & 256 & 61 & 23.8 \\
Happy Chinese & 371 & 143 & 38.5 \\
Approach to Chinese & 327 & 49 & 15 \\
Challenge Chinese & 802 & 162 & 20.2 \\
Standard Chinese 1 & 873 & 49 & 5.6 \\
Question and Answer for Chinese & 500 & 131 & 26.2 \\
Tianjin Dairy & 275 & 40 & 14.5 \\
Chinese Daily Reading and Dialogues & 432 & 78 & 18.1 \\
ALL & 8041 & 1526 & 19.0 \\
\hline
\end{tabular}

Note. The full names of textbooks have been listed in the Appendix.

Although there are a large proportion of homographs in Chinese learning, homographs in the textbook particularly focus on the ones with same forms but different meanings.

These homographs with same forms have totally different meanings as above, and teachers can avoid misusages by remembering meanings. Some of them with overlapping meanings can be easily taught, while others cannot. The most difficult part is some words with a part of overlapping meanings and also carries different meanings. 


\section{Reasonable Standards for Current Explanatory Notes}

In this section, the authors will discuss the homographs and notes, along with sentences from corpus which are tend to misuse, in a purpose of the study on the rationality of homographs meanings.

【new word】发表/発表

【example ${ }^{1}$ 】我发表的时候，你一定要来啊。/You must come when I do a presentation. (Chinese Time)

【new word】采用/採用

【example】他写的文章没被采用。/His article did not adopt. (To the Chinese)

【new word】提供/提供

【example】早餐提供到10点以前。/Breakfast is provided before $10 \mathrm{am}$. (Progress Everyday)

The above three homographs are verbs with significant differences in meanings between Chinese and Japanese. Especially the first word "published", the Chinese example itself has a linguistic problem. Although the writer of the textbook is a Chinese, he still misuses "publish" this word due to the Japanese influence. The writer collects three words and their sentences through corpus in order to have a better understanding of differences among these three homographs.

\section{发表/発表}

\section{Japanese「発表」}

Example $^{2}$ (5) J: 高柳の秘密——六左衛門との関係——すべてその卑しい動機から出た結婚の真 相が残るところなく発表された。『破戒』

C：他还毫不保留地揭发了高柳的秘密真相，说他和六左卫门的关系，和他女儿结婚， 全都出于这种卑鄙的政治动机。

E: He exposed the secretive truth without any reservation, which is his relationship with Liu Zuo guardian and marriage with his daughter is all due to his despicable political motivation.

Example (6) J: おい、緊急発表だ。みんな聞いておるか。いま云ったように、庄原の収容所へ行 きたい者は申し出ろ。『黒い雨』

C: 喂！紧急通知，大家都听着。刚才说过了，愿意到庄原收容所去的人提出来。

E: Hey! Emergency! Listen up, everyone. Like I said before, someone can tell me if he is willing to go to the Zhuangyuan Shelter.

Example (7) J:「じゃあまあ簡単だったわけですね」と僕は言った。発表はいつなんですか?」『ノ ルウェイの森』

C: “那么说，倒是真够容易的。”我说，“发榜在什么时候?”

E: "That is to say, it is so easy." I said, "when is the announcement?"

Example (8) J: そのひとは、戦後あたらしいタッチの画をつぎつぎと発表して急に有名になった 或る中年の洋画家の奥さんである。『斜陽』

C: 她是战后用新画法一连发表了许多作品而一举成名的某中年西洋画画家的夫人。

$\mathrm{E}$ : She is the wife of a middle-aged western painter who sprang into fame due to publishing a series of works by using new techniques after wars.

\section{Chinese “发表”}

Example (9) C: 您不知道, 我写的稿子每次退回来, 人家连封信也不给咱写呀。这回可好, 登门拜

\footnotetext{
1 These three examples are excerpted from texts or exercises in textbooks.

2 J stands for Japanese, C for Chinese, E for English.
} 
访了, 兴许有篇稿子能发表啦。《辘轳把胡同 9 号》

$\mathrm{J}$ : ご存じなからうが、これまで僕の原稿はいつもつき返され、中には手紙一本入って いなかった。それが今度は家までたずねてきたくらいだから、きっと僕の原稿が掲載 されることになっていたのでしょう。

E: Don't you know, they did not give me a letter when my manuscript returned every time. This time, even better, they visited me. Maybe I have an essay published. —No. 9 Lu Guba Lane

Example (10) C: 这本来是土改那会儿为了举手表决一些问题, 让他们集中坐在前边, 点人数或是发 表意见方便。《金土地》

$\mathrm{J}:$ それいうのも土地改革のとき、何がしかの問題を挙手によって表決するのに、 解放農家を前のほうへ集中的にすわらせたほうが、頭数を数えたり意見をのべたり するうえで便利だということがある。

E: These problems that supposed to vote for solutions during Land Reform. Please gathering people to sit in the front, it is convenient to count people or voice opinions.

- Golden Land

From the examples of corpus, the Chinese "publish” (“发表”) refers to announcement to the group or society or publishing in journals. The objectives of "publish" means "voice opinions" (Example (10)), "publish papers" (Example (9)), or "publish works" (Example (8)); while the Japanese "publish" (「発表」) carries the same meanings but more diversified. For instance, like Example (5), 真相が残るところなく発表された。」， the "truth" in Japanese can also use the verb "publish" (「発表」). However, due to suitable collocation, the authors can only say "expose (disclose) the truth" not "publish the truth" when translated into Chinese.

This is determined by the limitations of the objectives of "publish". In Example (6), Japanese "publish" (「発表」) which means “emergent notice” acts as noun, different from the Chinese "publish” (“发表”) which means “report” in Chinese. From the same aspect, “Articles can get published.” (“稿子能发表啦” in Chinese) cannot translate into「原稿が発表されることになっていた」. In Example (7), Japanese “publish”(「発表」) means "announcement", acting as a noun, which can not translate directly into "publish".

\section{采用/採用/adopt}

\section{Japanese「採用」}

Example (11) J: 新入社員を採用するかどうかを決めるために、たいていの企業は、会社訪間して くる学生に面接をします。『ひとりっ子の上手な育て方』

$\mathrm{C}$ : 为了招收新职工，一般公司都采取面试的方式。

E: In order to recruit new staff, ordinary companies adopt the method of interviews.

Example (12) J: 第二の人種は、アーリー・アダプター、直訳寸れば初期採用者で、十三・五\%いる。 『百言百話』

C: 第二类是early adapter, 初期录用者, 占百分之十三点五。

E: The second category is "early adapter", the initial candidate, accounts for $13.5 \%$.

\section{Chinese “采用”}

Example (13) C: 因为朱铁汉要采用的这个办法是他俩提的头。《金土地》

$\mathrm{J}:$ 朱鉄漢のこの計画はそもそもかれら二人がもち出したのである。

E: Because of them, Zhu Tiehan wants to adopt this method. —Golden Land 
Example (14) C: 西洋人说, 中国菜最进步, 最好吃, 最合于卫生标准 : 所以他们采用中国菜。 《彷得》

$\mathrm{J}:$ 中国料理はもつとも進歩しており、もつともおいしくて、もっとも衛生的である、 と西洋人が言っている。だから彼らは中国料理を採用したのだ。

E: Western people say that, Chinese dishes is the most progressive, the most delicious and conforms to hygiene standard, so they use Chinese dishes. - Hesitating

The objectives of Japanese “adopt” (「採用」) includes systems, strategies, methods, and people; while the counterparts of Chinese “adopt” (“采用”) cannot be people, such as Japanese “adopt” (「採用」) translated into "candidate" and "recruit" in Examples (11) and (12). However, in Example (13), "adopt" is not present in Japanese translated version; while "adopt" in Example (14) also use homograph "adopt" in Japanese.

\section{提供/提供}

Japanese「提供」

Example (15) J: 私の生命の維持が、私の属し、そのため私が生命を提供している国家から保障さ れる限度は、この六本の芋に尽きていた。この六という数字には、恐るべき数学的 な正確さがあった。『野火』

C: 维持我生命的, 就只有这六个芋头, 而这就是我全身都属于它、并将为它献出我的 生命的国家所能给我的最大限度的保障。“六”这个数字，此时就具有一种可怕的、数 学的准确性。

\section{Chinese “提供”}

E: Only these six taro can maintain my life and this is the maximum guarantee that my country I devoted my life can provide. The number "six" has a horrible accuracy.

Example (16) C: 说着, 他向贝蒂小姐点了点头, 似乎为自己提供的情况与贝蒂不同而感到歉意。《活》 $\mathrm{J}:$ 彼はべティ嬢に軽くうなずいた、自分の提供した情報が彼女と異なることを詫び るかのように。

E: He nodded to Miss Betty, seems feeling apologetic for different situation provided between them.

Example (17) C: 这是因为, 祖国的解放给我提供了一条我家祖祖辈辈不曾有人走过的道路, 我成了 我的家族中第一个读书的女孩子，第一个受完高等教育的人。《人啊，人》

$\mathrm{J}$ : 党と社会主義に対する私の気持ちには一点の偽りもなかった。というのは、祖国 の解放は私に、わが家では先祖代々だれも進んだことのない道を用意してくれたか らである。私はわが家で最初に学校に上がった娘、そして最初に大学教育を受けた人 間となった。

E: This is because, the liberation of the motherland gives me a different path that my ancestors never walked on, I became the first girl to study, the first people finished higher education in my family.

The objectives of Japanese "provide" (「提供」) can be "life" (as in Example (15)), while Chinese "provide" (“提供”) cannot be "life". The objects of Chinese "provide" may be specific data, also can be abstract "situation" (as in Example (16)), "path" (as in Example (17)). Compared with Japanese, the objectives of Chinese "provide" are abstract nouns for the most of them.

From the above analysis, although homographs share same forms and overlapping meanings, there are also 
differences in meanings and usages. The meanings and usages differ in varied contexts, cannot simply correspond to the same Chinese characters. The most of explanatory notes use simple correspondents by using homographs with same forms in current Chinese textbooks published in Japan, amplifying consistency and neglecting differences.

\section{New Notes Method of New Words}

Given the current issue, the author assumes that the textbook can provide explanations of homographs along with collocations, leading to reduce misusages. The solution is shown in Table 2.

Table 2

Suggestions on Explanatory Notes of New Words

\begin{tabular}{|c|c|c|}
\hline New words & Japanese notes & Collocations \\
\hline 发表 & 発表 & publish at... (发表于........); voice opinion (发表意见); publish books (发表著作) \\
\hline 采用 & 採用 & $\begin{array}{l}\text { adopt... method (采用 } \cdots . . . . \text { 方法); taking... advice (采用 } . . . . . \text { 建议); using... system } \\
\text { (采用……制度) }\end{array}$ \\
\hline 提供 & 提供 & $\begin{array}{l}\text { provide... information (提供……情况); provide... opportunity (提供 } \cdots . . . . \text { 机会); } \\
\text { provide... convenience (提供……方便) }\end{array}$ \\
\hline
\end{tabular}

\section{Conclusion}

This paper studies on the explanatory notes of homographs from 16 elementary Chinese textbooks published in Japan. According to the study result, the number of homograph accounts for one fifth (1/5) among all the new words. But the explanatory notes of those words may be simple same word notes. In addition, many textbooks only introduce homographs with same forms and different meanings in "Knowledge" section, which aims to master specific meanings of those words. But for those words with most of semantics and usage overlapping but still have different ones, the author suggests that simple explanations and collocations may be helpful for students' learning memory by phrases. Thus, it can be conducive to mastering of meanings and usages of homographs, reducing the misusages.

\section{References}

Arakawa, K. (1979). Chinese and Chinese words - Comments on Chinese words in Japanese responding to Chinese from the Ministry of Culture. Aichi University Paper Journal, (62), 1-28.

Cook, V. (2000). Second language learning and language teaching (2nd ed.). Beijing: Foreign Language Teaching and Research Press.

Dictionary Editing Office in Institute of language of Chinese Academy of Social Sciences. (2012). Modern Chinese dictionary (6th ed.). Beijing: The Commercial Press.

Hanban/Confucius Institute Headquarters. (2011a). HSK test syllabus (Level two) (p. 1). Beijing: The Commercial Press.

Hanban/Confucius Institute Headquarters. (2011b). HSK test syllabus (Level three) (p. 1). Beijing: The Commercial Press.

Okochi, Y. (1992). Chinese-Japanese homograph. In Comparative study papers on Japanese-Chinese (II) (pp. 179-215). Tokyo: Kuroshio Press.

SHI, J. J. (2013). The current situation and subjects of synchronic comparative studies of Chinese-Japanese homographs. Foreign Language Research in Northeast Asia, (1), 4-9.

Shinmura, I. (2008). Köjien. Tokyo: Iwanami shoten, Publishers.

ZHANG, Y. (2001). An analysis of teaching material in Japan. Chinese Learning, (3), 61-69. 
Appendix: Textbook List

\begin{tabular}{|c|l|l|l|l|}
\hline No. & Textbooks & Publish company & Author & Publish time \\
\hline 1 & To the Chinese & Asahi press & Yang Kairong, Zhang Liqun & $2008 / 1$ \\
\hline 2 & Kumi Shanghai Trip & Surugadai Press & KURAMOI Takafumi, OHZAWA Riko & $2008 / 4$ \\
\hline 3 & Chinese College & Ikubundo Press & TAKENOBU Akira & $2008 / 4$ \\
\hline 4 & Chinese Time & Asahi Press & OHMORI Shinri & $2007 / 4$ \\
\hline 5 & Chinese Bridge & Surugadai Press & $\begin{array}{l}\text { Wang Shunhong, HIRANO Kazuhiko, NAWA } \\
\text { Toshimitu }\end{array}$ & $2007 / 4$ \\
\hline 6 & Campus Life in Chinese & Asahi Press & Zhang shiying, Shen Lihua & $2007 / 4$ \\
\hline 7 & Open the door! Chinese & Asahi Press & KOIKE Ichiro, NAWA naosuke & $2008 / 1$ \\
\hline 8 & $\begin{array}{l}\text { Instantly use Chinese-Unforgettable } \\
\text { Times }\end{array}$ & Ikubundo Press & $\begin{array}{l}\text { Yang Guangjun, Zhang Ping, WATANABE } \\
\text { Shuji }\end{array}$ & $2006 / 4$ \\
\hline 9 & Progress Everyday & Hakuteisha Press & SATO Haruhiko & $2007 / 4$ \\
\hline 10 & $\begin{array}{l}\text { Happy Chinese-Tomoko's Beijing } \\
\text { Study Life }\end{array}$ & Ikubundo Press & UENO Eiji & $2006 / 11$ \\
\hline 11 & Approach to Chinese & Asahi Press & Yang Kairong, Zhang Liqun & $2006 / 4 / 1$ \\
\hline 12 & Challenge Chinese & Ikubundo Press & $\begin{array}{l}\text { SAIJO Masaru, TANIGAWA Eiko, NISHII } \\
\text { Katsuya }\end{array}$ & $2006 / 4$ \\
\hline 13 & Standard Chinese 1 & Asahi Press & YAGI Shoko & $2006 / 4$ \\
\hline 14 & Question and Answer for Chinese & Asahi Press & Zhu Jizheng & $2006 / 4$ \\
\hline 15 & Tianjin Dairy & Asahi Press & WATANABE Haruo, Wu Hongchun & $2006 / 4$ \\
\hline 16 & Chinese Daily Reading and Dialogues & Asahi Press & Fan Jianming, Shen Lihua, Zhang Shiying & $2006 / 4$ \\
\hline
\end{tabular}

